\title{
THE CULTURAL INSTITUTIONALISATION OF PHOTOGRAPHY IN FRANCE: A BRIEF HISTORY
}

\section{KATHRIN YACAVONE}

On 19 August 1839, the physicist, astronomer and politician François Arago delivered a powerful rapport in front of the Parisian Académie des Sciences, in which he announced and vividly described the invention of the photographic process by Nicéphore Niépce and Louis Daguerre. After recognising the great potential of photography for the arts and sciences owing to its detailed image capturing, Arago concluded on a patriotic note, alluding to the fact that the French government had recently acquired the rights to the invention: 'Cette découverte [the daguerreotype process], la France l'a adoptée; dès le premier moment, elle s'est montrée fière de pouvoir en doter libéralement le monde entier'. ${ }^{1}$ This act, and its announcement, represented the first step in the French government's appropriation of the then new image reproduction technology presented as a distinctly French contribution to world culture.

However, if the French state 'adopted' photography to grant it to the rest of the world, according to Arago's ostentatious rhetoric, surprisingly it would take no less than a century and a half before an active and coordinated cultural politics of photography, as it might be called, was pursued. And this is despite a strong tradition of state involvement in cultural and artistic affairs, ranging from the fine arts to music, theatre and later cinema (very early on in its history), fully institutionalized at the beginning of the Fifth Republic in the form of a

\footnotetext{
${ }^{1}$ François Arago, Le Daguerréotype (Paris: L’Échoppe, 2003), p. 23.
} 
Ministry of Culture. ${ }^{2}$ France's first culture minister, the novelist, essayist and art theorist André Malraux, was of course no stranger to photography. Published in 1947, his Musée imaginaire famously celebrates the profoundly new understanding and appreciation of paintings, sculptures and other art works from different periods and cultures as juxtaposed with one another - and experienced by a much larger public - in the form of photographic images. However, and perhaps reflecting the largely instrumental role granted to photography in his concept and practice of the 'museum without walls', in which the medium served as but the vehicle for traditional artistic representation and expression, as minister Malraux did little to reverse the tradition of failing to make a space for photography as an officially promoted and financially supported French artistic and cultural practice (as distinct from its officially supported historical/archival and scientific applications). ${ }^{3}$ This neglect was most likely a reflection of the widely held view in some quarters persisting as late as the 1960s that photography was not an art in its own right, in the way that painting and cinema, for instance, were, even if it could be harnessed for artistic purposes (as in Malraux's work). Such a position can be traced back to nineteenth-century debates concerning the status of photography as art, and, specifically, to Charles Baudelaire's famous critique of the 1859 Salon, in which photography was exhibited alongside traditional fine art for the first time.

${ }^{2}$ For an overview of France's cultural politics from the mid-nineteenth century onwards, see Philippe Poirrier, L'État et la culture en France au XX $X^{e}$ siècle (Paris: Le Livre de Poche, 2009).

${ }^{3}$ Cf. Michel Frizot, 'Politique de la photographie', in Dictionnaire des politiques culturelles de la France depuis 1959, ed. by Emmanuel de Waresquiel (Paris: Larousse, 2001), pp. 4959 (p. 496). 
In the section of his Salon review entitled 'Le Public moderne et la photographie', Baudelaire accuses the contemporary populous of accepting and celebrating a positivistic 'goût exclusif du Vrai', ${ }^{4}$ which photography fuelled. Beginning with the 1854 invention of the carte-de-visite process, which allowed for relatively inexpensive mass-production of photographic portraits, photography, for Baudelaire, became an 'industrie' as opposed to an art, and must now wholly accept its role as 'la servante des scienes et des arts, mais la trèshumble servante'. ${ }^{5}$ Baudelaire's assessment not only fuelled dichotomies with which photography was subsequently yoked - art versus technology, fiction versus document, subjectivity versus objectivity, illusion versus reality etc. - but also helped to shape the French public and governmental discourse on photography all the way up until the later third of the twentieth century.

It was in the 1970s and 1980s that photography is generally considered to have been fully embraced by French cultural and political institutions, both in parallel with, but also in response to, its widespread recognition as a fully-fledged fine art by the international artistic establishment. However, it must be stressed that a number of pioneering initiatives by individual enthusiasts engaged in valorising photography as an in-itself valuable artistic (or otherwise culturally significant) activity in the form of events, galleries and editorial projects, for example, preceded the official move towards a centralized and cogent cultural politics of the medium. In fact, in looking more closely at the historical specifics of photography's

\footnotetext{
${ }^{4}$ Charles Baudelaire, 'Salon de 1859', in Euvres complètes, ed. by Yves-Gérard Le Dantec (Paris: Gallimard/Bibliothèque de la Pléiade, 1954), pp. 761-80 (p. 769).

${ }^{5}$ Ibid., p. 771.
} 
cultural institutionalisation from the 1970 s onwards,${ }^{6}$ it is clear that in many respects rather than lead the way in prospective fashion, an official cultural politics of photography began to emerge in a relatively uncoordinated and piecemeal fashion in the wake of changes on the ground, as it were, seen here to include changes in archival and exhibition practices in French libraries and art museums, and the creation of dedicated photography museums.

\section{Individual enthusiasts and early initiatives}

Despite its increasingly ubiquitous presence of photographic images in the visual landscape of mid-twentieth-century life, and the medium becoming a subject of academic study (including in the seminal semiotic and sociological writings of Roland Barthes and Pierre Bourdieu respectively ${ }^{7}$ ), the 1950 s and '60s saw no significant public initiatives related to the multifaceted cultural and artistic nature and capacity of photography, nor to the history of the medium. Indeed, it can be argued, following Christian Gattinoni, that up until the mid-1970s, most activity in this direction was initiated by individual enthusiasts on a notably regional rather than national basis. ${ }^{8}$ These included, for example, amateur photographers Jean and

\footnotetext{
${ }^{6}$ While the institutional history of photography is relatively well documented in a Frenchlanguage context, as evident from the sources this article draws on, there is no comparable overview in English.

${ }^{7}$ See especially, 'Le Message photographique' (1961) and 'Rhétorique de l'image' (1964) by Roland Barthes, in Euvres complètes, ed. by Éric Marty, 5 vols. (Paris: Seuil, 2002), vol. 1, pp. 1120-33; vol. 2, pp. 573-88; and Un Art moyen. Essai sur les usages sociaux de la photographie, ed. by Pierre Bourdieu (Paris: Éditions de Minuit, 1965).

${ }^{8}$ Christian Gattinoni, La Photographie en France, 1970-2005 (Paris: Panoramas/CulturesFrance, 2006), p. 30.
} 
André Fage who founded the Museé français de la photographie in Bièvres (located close to Paris in the Département de l'Essonne) in 1960, which specializes in the early history of photographic technology. Apart from establishing permanent exhibition spaces and museums, such private initiatives also encompassed the creation of festivals, conferences, marketplaces and temporary exhibitions.

Another important milestone was the formation of the Rencontres internationales de la photographie in Arles in $1970 .{ }^{9}$ Led by an diverse group of photography enthusiasts, including the photographer Lucien Clergue, Jean-Claude Lemagny, director of what was then still called the Cabinet des Estampes of the Bibliothèque nationale de France, Maurice Rouquette and the writer Michel Tournier, the Rencontres established an influential photography community in the South, one which continues to the present day in the form of a programme of public debates and events, supplementing exhibitions often showcasing the bodies of work of individual photographers. The innovative nature of the Rencontres in the 1970s (under the directorship of Lucien Clergue) was typified by the presentation of the work of seminal French photographers, including Brassaï, Robert Doisneau and Henri CartierBresson; but also American photography by Ansel Adams, for example, hitherto little seen by the French public. Although critics have sometime pointed to a lack of coherent vision and orientation, towhich the rather short tenure of directors has perhaps contributed, ${ }^{10}$ the

\footnotetext{
${ }^{9}$ For a concise overview of the history of the Rencontres, see Michel Frizot's entry 'Rencontres internationals de la photographie (RIP)', in Dictionnaire des politiques culturelles de la France depuis 1959, ed. by Emmanuel de Waresquiel (Paris: Larousse, 2001), pp. 548-9.

${ }^{10}$ See ibid.
} 
Rencontres have nonetheless remained a significant annual occasion for photography specialists and amateurs alike to view and debate past and present photographic work.

Against the background of the province having its signature photography event, in the form of the Rencontres, a number of individuals attempted to interest local authorities in the French capital in similar initiatives. ${ }^{11}$ Prominent among these was Jean-Luc Monterosso who, together with Henry Chapier, Marcel Landowski and Francis Balagna, established the association Paris Audiovisuel in 1978 in order to promote the creation and dissemination of artistic photography in Paris. ${ }^{12}$ The fact that they managed to secure public funding from the Hôtel de Ville in order to support cultural initiatives with regards to a medium that had hitherto received little political attention (national or regional) may in itself speak to an emerging politicisation of photography. In 1977 Jacques Chirac was elected as Mayor of Paris, an office which had been in a century-long abeyance. Given Chirac's national political ambitions and in the context of rivalry between the liberal national government of Giscard d'Estaing and the Parisian municipal authorities, in cultural affairs and beyond, promotion of photography fell on fruitful ground, so to speak, as it provided an apparently democratic medium fit for Chirac's political programme of urban and cultural innovation in France's capital.

With funding from the municipal authorities, Paris Audiovisuel henceforth provided the administrative structure for the emerging Mois de la Photo, a biannual event initiated by Monterosso in 1980. Combining exhibitions of photography from France and elsewhere with conferences and colloquia, and a photography auction, the aim was to transform Paris 'en une formidable cimaise où chacun pourra trouver son parcours', as Monterosso declared in a press

\footnotetext{
${ }^{11}$ See Gattinoni, La Photographie en France, p. 30.

${ }^{12}$ See the interview with Monterosso in this volume.
} 
statement in $1980 .{ }^{13}$ The immediate success of this eclectic format led to a quick succession of Mois de la Photo outside of France, including European cities such as Barcelona and Rotterdam, as well as North American ones, such as Montreal and Houston (the latter being more commercially oriented). ${ }^{14}$ Since 1998 the Parisian version has been affiliated with the Paris Photo salon, an international photography fair (which first took place in 1997), ${ }^{15}$ and since then has also been closely aligned with the Maison européenne de la photographie (MEP), a major photographic institution.

One year after Chirac's departure from his office as Mayor of Paris, the MEP was opened in 1996 by the Hôtel de Ville in the restored Hôtel de Cantobre in the Marais quarter, in close proximity to the Galerie Agathe Gaillard, the first Parisian gallery devoted to photography, ${ }^{16}$ and the Hôtel de Sully, which houses the Centre des monuments nationaux,

${ }^{13}$ Interphotothèque. Actualities, 18 (1982), p. 5. This bulletin, published between 1977 and 1991 by the Documentation française, the official organ of the Ministry of Culture, was intended to communicate publically funded developments and news in relation to photography.

${ }^{14}$ See Stuart Alexander, 'L'Institution et les pratiques photographiques', in Nouvelle histoire de la photographie, ed. by Michel Frizot (Paris: Larousse, 2001), pp. 695-707 (p. 704).

${ }^{15}$ See Gaëlle Morel, 'Entre art et culture. Politique institutionnelle et photographie en France, 1976-1996', Études photographiques, 16 (2005), 32-40 (p. 38).

${ }^{16}$ The gallery opened in 1975 and its owner, Agathe Gaillard, must be counted among the true pioneers in elevating the cultural and artistic status of photography in France. Her recently published memoir is a vivid account of the history of her gallery, including of the difficulties of promoting photography as art in the mid-1970s and its later success. See Agathe Gaillard, Mémoires d'une galerie (Paris: Gallimard, 2013). 
France's cultural heritage administration. ${ }^{17}$ A more permanent home for exhibitions and activities surrounding photography than its direct predecessor, the Espace Photo du Forum des Halles (1986-96), the MEP has since organised eight to ten photography exhibitions per year, under the directorship of Monterosso. As Gaëlle Morel has emphasized, with its multiple gallery spaces, a specialist library and médiathèque, an auditorium and the more recent installation of a restoration laboratory, the MEP is 'un lieu culturel dédié à la photographie, et non un simple musée'. ${ }^{18}$ The MEP's innovation - alongside the aforementioned photography museum in Bièvres and the Musée Nicéphore Niépce in Chalonsur-Saône (which was opened in 1974) - is not confined to its being a space explicitly dedicated to photography, ${ }^{19}$ but also owes to the fact that it has assembled its own collection. With an emphasis on photography from the 1950s onwards, it includes post-war French and Japanese photography, the work of important American photographers, such as William Klein and Robert Frank, as well as contemporary photographic work from around the world. ${ }^{20}$

${ }^{17}$ Frizot points out that there were plans to establish a Galerie nationale de la photographie in the Hôtel de Sully, before the founding of the MEP, which have, however, never been realised ('Politique de la photographie', p. 499).

${ }^{18}$ Morel, 'Entre art et culture', p. 37.

${ }^{19}$ Sylvain Maresca usefully distinguishes between fine art collections which comprise photography and institutions which pursue an exclusively photographic programme, see 'Puisque c'est un art désormais', in Une Aventure contemporaine, la photographie 19551995. Regards sur la création photographique contemporaine (Paris: MEP/Paris Audiovisuel, 1996), pp. 91-9 (pp. 94-5).

${ }^{20}$ I take this information from <http://www.mep-fr.org/la-maison/la-collection/le-fondsphotographique/> [accessed 1 August 2013]. 


\section{Photography and fine art collections}

As already noted, since its invention, photography, the result of mid-nineteenth-century scientific and technological advancement, struggled to receive institutional and political recognition as art (broadly defined) as distinct from only technical craft, to evoke Immanuel Kant's distinction. In France, this battle has been particularly pronounced owing to the traditionally strong concept of beaux arts and the clear normative demarcation between socalled high and low art, or, non-art, ${ }^{21}$ with writers such as Baudelaire using photography (associated with the latter) as the very basis for the loaded dichotomy. While photography's artistic status was 'en voie de légitimation' during the 1960 s, as Bourdieu suggests, ${ }^{22}$ the subsequent decade is most commonly considered to mark the decisive turning point in the institutional acknowledgement of photography as fine art in Europe, the USA and beyond. ${ }^{23}$ In a French context, this took the form of a paradigm shift in collection and acquisition policies of major national fine art museums, from an almost entire neglect of photography, ${ }^{24}$ to influential acquisition and exhibition policies, reflecting a larger transition from a more narrow definition of beaux arts (confined to non-mechanically produced art) to a more

\footnotetext{
${ }^{21}$ Maresca makes this point in 'Puisque c'est un art désormais', p. 98-9. Frizot similarly
} argues that the elitist notion of art in France was detrimental to the integration of photography into established fine art institutions, 'Politique de la photographie', p. 496.

${ }^{22}$ Un Art moyen, ed. by Bourdieu, pp. 136-7.

${ }^{23}$ For an in-depth treatment of this question, see Michael Fried, Why Photography Matters as Art as Never Before (New Haven and London: Yale University Press, 2008).

${ }^{24}$ See La Photographie. Dix ans d'enrichissement des collections publiques, ed. by Philippe Néagu (Paris: Réunions des musées nationaux, 1992), p. 19. 
technologically inclusive one of arts plastiques. ${ }^{25}$ This shift has also been described as one from considering photography primarily as a historical and archival document to viewing photographs through the lens of their rarity as physical objects and a certain practical 'purposelessness' (as associated with art and the aesthetic since Kant). ${ }^{26}$ Two major museums, both conceived during the height of this transition, were also instrumental to it: the Musée national d'art moderne housed in the Centre Georges-Pompidou and the Musée d'Orsay.

The initial creation of a photography collection in these national museums was consciously modelled on the Museum of Modern Art in New York, as the world-leading institution in this respect, ${ }^{27}$ which has been pursuing an active policy of photography acquisition and exhibition since the 1930s (under the egis of Beaumont Newhall, its first curator of photography, whose History of Photography, first published in 1949, remains a classic in the field). In France, while the very first photographic works entered the collection of the Musée national d'art moderne in the form of donations in the early 1970s, the first official acquisitions date from 1976, one year before its opening to the public. ${ }^{28}$ Meanwhile, the nineteenth-century photography collection of the Musée d'Orsay, with its focus on the work of artists born in or before 1870, started from scratch in 1979 and, by the time of its opening in 1986, was the first beaux-arts museum in France to feature a dedicated

\footnotetext{
${ }^{25}$ See Maresca, 'Puisque c'est un art désormais', p. 93.

${ }^{26}$ See ibid., pp. 91-2.

${ }^{27}$ See Quentin Bajac, 'Stratégies de légitimation. La photographie dans les collections du musée national d'art moderne et du musée d'Orsay', Études photographiques, 16 (2005),
} $222-33$ (p. 226).

${ }^{28}$ See ibid., pp. $224-5$. 
photography section. ${ }^{29}$ Three years later, and the year of the $150^{\text {th }}$ anniversary of the first public announcement of photography, two landmark exhibitions took place at the Musée d'Orsay and the Musée national d'art moderne: L'Invention d'un regard and L'Invention d'un art, respectively, which are justly seen to mark the 'sommet de reconnaissance institutionelle' of photography, ${ }^{30}$ and its permanent place in French art collections, comparable in their significance with respect to photography's cultural institutionalisation to a series of seminal exhibitions at New York's MoMA in the 1930s. ${ }^{31}$

\section{Photography in the Bibliothèque nationale de France}

Although as a result of this shift concerning the fine art status (or potential) of the medium, photography became an increasingly prominent feature of public art museums, on the basis of their archival-historical interest, photographic images had always been a part of history

${ }^{29}$ See <http://www.musee-orsay.fr/fr/collections/histoire-des-collections/photographie> [accessed 1 August 2013]. However, it is difficult to disagree with Gattinoni who remarks that the museum does not provide the appropriate space to photography that its actual impact on nineteenth-century society and culture would deserve, see La Photographie en France, p. 38.

${ }^{30}$ Gattinoni, La Photographie en France, p. 38.

${ }^{31}$ However, as Christopher Phillips has argued, these photography exhibitions at the MoMA failed to significantly impact on the wider cultural context of the art-world at the time, see 'The Judgement Seat of Photography', in The Contest of Meaning: Critical Histories of Photography, ed. by Richard Bolton (Cambridge, MA and London: MIT Press, 1996), pp. $14-47$ (p. 23). 
museum collections in France, including that of the Musée Carnavalet, for example. ${ }^{32}$ The same is true of libraries, as Quentin Bajac has pointed out, ${ }^{33}$ and the most important example is the photography collection of the Bibliothèque nationale de France $(\mathrm{BnF})$.

The history of the photography collection of the BnF can aptly be described as a part of 'l'histoire de la photographie elle-même', ${ }^{34}$ due to the fact that from 1851 onwards many photographers donated their work to the library and to the requirement of the dépôt légal of photography since 1925 , which entails required submission to the library of printed documents which include photographic reproductions (ranging from posters and postcards to photographic albums and catalogues). Over the years, this collection has expanded thanks to significant donations and targeted acquisitions of photographic œuvres, and it is now one of the largest collections of photography in France, especially of nineteenth-century and early twentieth-century images, including the major bulk of the work of Nadar and Atget, to name but the most famous French photographers of these periods. ${ }^{35}$ Together with an explicit acquisition policy governed by the idea of centralising the French partimoine, with respect to photographic images, dating back to the post-war years, the BnF's photography collection

${ }^{32}$ For a comprehensive list of these institutions and the focus of their collections, see $\mathrm{La}$ Photographie. État et culture (Paris: La Documentation française, 1992), pp. 45-52.

${ }^{33}$ See Bajac, ‘Stratégies de légitimation', p. 224.

${ }^{34}$ Sylvie Aubenas, “"Magique circonstancielle”. Le Fonds de photographies du XIX ${ }^{\mathrm{e}}$ siècle au départment des estampes et de la photographie de la BnF', Études photographiques, 16 (2005), 210-21 (p. 211).

${ }^{35}$ Since 1993, the BnF also houses the collections of the Société française de photographie. Founded in 1854, it is the oldest active photography society and possesses its own photography and collection. See <http://www.sfp.asso.fr/> [accessed 1 August 2013]. 
was also expanded and reclassified - tellingly according to photographers' names rather than subject matter - as a result of the photography's new-found fine art status in the 1970s. In 1976, the Cabinet des estampes was transformed into the Département des estampes et de la photographie, and, under its dynamic director Jean-Claude Lemagny (who co-founded the Rencontres in Arles), saw a number of initiatives, notably the creation of a permanent exhibition space (the Galerie Mansart at the historic site on the Rue Vivienne) entirely dedicated to photography. Since the opening of the new site on the Quai François-Mauriac in 1996, a better infrastructure and larger exhibition spaces have allowed for more sizable and regular photography exhibitions,${ }^{36}$ often also in conjunction with the Mois de la Photo (such as La Photographie en 100 chefs-d'œuvre in 2012), drawing on the library's collection. In sum, and paralleling the situation in other countries (including the United States), the widespread recognition of photography as an art form and a vital cultural force on par with traditional arts and cinema, for instance, which took place during the 1970s, has not only had a major impact on photography's place in French fine art museums, but other institutions collecting and preserving photographic images. ${ }^{37}$

\section{The Cultural Politics of Photography}

Considering the exceptional involvement of the French government at the moment of the medium's inception, it may perhaps surprise that an active cultural politics of photography is

${ }^{36}$ See Aubenas, “"Magique circonstancielle”, p. 213.

${ }^{37}$ See Douglas Crimp's discussion of the changing conception, and re-categorisation, of the photography collection of the New York Public Library, 'The Museum's Old, the Library's New Subject', in The Contest of Meaning: Critical Histories of Photography, ed. by Richard Bolton (Cambridge, MA and London: MIT Press, 1996), pp. 3-12 (pp. 6-8). 
relatively recent, as Frizot has remarked. ${ }^{38}$ This is especially surprising given that concrete governmental activity involving photography began almost immediately after its announcement in 1839. Perhaps inspired by Arago's suggestion as to photography’s archaeological potential (with reference to the monuments of ancient Egypt, and the deciphering of hieroglyphs specifically), ${ }^{39}$ the Commission des monuments historiques established a collection of daguerreotypes of ancient buildings in France. More well-known, in 1851, the Interior Ministry commissioned five photographers with the Mission héliographique, an innovative project with the aim of documenting France's historic buildings in the photographic medium. This truly 'monumental' project was the first state-funded photography project in France's history. Nonetheless, as has been suggested, it would take well over a century for an active politics of photography, as a means of promoting both culture in France and French culture worldwide, to emerge.

Although the official organ of the Ministry of Culture, La Documentation française, describes 1975 as a 'date-charnière' in the history of photography's cultural institutionalisation, ${ }^{40}$ the governmental initiatives under Valéry Giscard d'Estaing remained rather tentative. However, this year did see the announcement by the culture minister, Michel Guy, of a Service de la photographie, a primarily administrative body whose function was mainly to coordinate (and harmonize) all photography-related cultural activities. ${ }^{41}$ The leadership of this Service was taken by Agnès de Gouvion Saint-Cyr, who has since played a key role in the cultural politics of photography for over thirty years, earning her the

\footnotetext{
${ }^{38}$ See Frizot, 'Politique de la photographie', p. 495.

${ }^{39}$ See Arago, Le Daguerréotype, p. 15.

${ }^{40}$ La Photographie. État et culture, p. 40.

${ }^{41}$ See Interphotothèque. Actualities, 2 (1978), pp. 1-2.
} 
description, by Claude Nori, as the 'véritable mémoire de la photographie française'. ${ }^{42}$ In 1978, the year of the foundation of Paris Audiovisuel by the Parisian Hotel de Ville, a Fondation nationale de la photographie was established, with Pierre de Fenoyl as its director. It was housed in the Château Lumière in Lyon, reinforcing the connection between still photography and cinema, already apparent in the financing of the Service de la photographie, which was, initially at least, taken from the budget for the Centre national de la cinématographie. ${ }^{43}$ With these new organizations in place, the French government hoped to make a decisive step in the direction of a cultural institutionalisation of the medium and, harking back to the nineteenth-century rhetoric concerning photography, declared that '[1]a photographie devrait ainsi progressivement retrouver par la politique culturelle menée en France le prestige dont elle bénéficiait lors de sa découverte'. ${ }^{44}$ Together with celebrating the French invention of photography and its prestige in nineteenth-century French culture, this official statement also, and for the first time, implicitly acknowledged a long period of governmental neglect. Such neglect would be greatly rectified under the leadership of Jack Lang, who it must be said reacted to local and regional activities, including those already mentioned, which he sought to frame, a posteriori, and centralize in political and institutional terms.

Apart from Malraux himself, no other culture minister has influenced the cultural landscape of twentieth-century France to a greater extent than Lang, as has often been noted.

\footnotetext{
${ }^{42}$ Nori, La Photographie en France. Des origins à nos jours (Paris: Flammarion, 2008), p. 312.

${ }^{43}$ See Morel, 'Entre art et culture', p. 34. The foundation in Lyon closed in 1993 to make space for the Institut Lumière.

${ }^{44}$ Interphotothèque. Actualities, 2 (1978), p. 3.
} 
Arriving at the rue de Valois under the socialist government of François Mitterrand in 1981 (within which he stayed, with only one two-year interruption, until 1993), Lang presided over the most intense period of governmental activity with respect to the promotion of photography. In the wake of the constitution of the Délégation aux arts plastiques in the early 1980s, the Mission pour la photographie became henceforth the overarching administrative unit (under the continued leadership of de Gouvion Saint-Cyr) which supervises all photography-related activities as well as the distribution of funds and the dissemination of the photographic heritage. Against the backdrop of a doubling of the national budget for culture under Lang, ${ }^{45}$ it also has the Fonds national d'art contemporain (FNAC) at its disposal, which includes a fund specifically dedicated to the acquisition of photography.

However, as Morel has explained, the primary photography organisation of the Ministry of Culture became the Centre national de la photographie (CNP) in $1982 .{ }^{46}$ In his July speech on the new governmental directions and initiatives with respect to photography, the culture minister described the current Zeitgeist as a desire for the recognition of 'la place de la photographie dans la grande famille des arts plastiques' and called for more extensive political action in this respect, while simultaneously acknowledging that

un pays comme la France, inventeur et berceau de la photographie, n'a peut-être pas donné à la photographie, à l'art de la photographie, à l'enseignement de la photographie, à la diffusion de la photographie, la place pleine et entière qu'elle mérite. $^{47}$

${ }^{45}$ See Poirrier, L'État et la culture, pp. 160-1.

${ }^{46}$ See Morel, 'Entre art et culture', p. 35.

${ }^{47}$ Jack Lang, 'Photographie: les nouvelles orientations', Interphotothèque. Actualities, 18 (1982), 1-5 (p. 1) 
The actions that followed this speech demonstrate that Lang was indeed committed to remedying this situation - even if photography was already gaining a more visible place in French culture, in his words, sans the support he mentioned. The creation of the CNP was Lang's major institutional contribution in this context.

Modelled, like the Musée national d'art moderne and the Musée d'Orsay, on a New York-based predecessor, the International Centre of Photography (which is, however, a private institution), as Lang acknowledges, ${ }^{48}$ the CNP was directed by Robert Delpire, ${ }^{49}$ a household name in the French photography scene since the 1950s, when he first began to exhibit photography in his gallery and to edit innovative monographs of the work of French and American photographers (such as Brassaï, Cartier-Bresson, Doisneau and Lartigue, as well as Robert Frank) under the label Éditions Delpire. The major charges of the CNP were to disseminate photography and to fulfil an educational function, or to 'sensibiliser à la photographie le public le plus large possible', ${ }^{50}$ for which touring exhibitions as well as the vast exhibition space in the Palais de Tokyo (from 1984 to 1993), provided the key means. The CNP also initiated a major publication programme, the distinctively black coloured Photo Poche series, with each small-format volume dedicated to the work of one photographer (the first in the series was on Nadar), or specific themes, such as the history of the medium, or specific genres of photography. The inauguration of the Jeu de Paume as the key national museum of photography on the Place de la Concorde in 2004 marks the end or, perhaps better

${ }^{48}$ Ibid., p. 2.

${ }^{49}$ For a concise summery of the history of the CNP, see Michel Frizot 'Centre national de photographie', in Dictionnaire des politiques culturelles de la France depuis 1959, ed. by Emmanuel de Waresquiel (Paris: Larousse, 2001), pp. 110-11.

${ }^{50}$ Lang, 'Photographie', p. 3. 
put, latest metamorphosis of the CNP, with the Jeu de Paume taking over the latter's collection and mission, together with that of the Patrimoine photographique. Dedicated from the start to photographic imagery broadly defined, 'dans une approche ouverte et transversale sur le plan chronologique du XIX ${ }^{\mathrm{e}}$ siècle à nos jours, comme sur le plan des différentes pratiques d'images (photo, cinéma, vidéo, installations...)', the Jeu de Paume also showcases virtual projects specifically designed for the Internet (since 2007). ${ }^{51}$ The opening of this museum can be seen as a continued political commitment to the evolving institutionalisation of photography, which in the 1980s peaked a second time, as it were, at the occasion of the medium's $150^{\text {th }}$ anniversary.

Given the projects and initiatives of the early 1980s, during a press conference on 1 June 1989, Lang could look back at a number of years of increased funding and public activity in relation to photography and assert, with some justification at least, that the decisive political action he inaugurated had paid off:

Aujourd'hui, on voit se dessiner les effets d'une politique qui a eu pour l'objet d'intégrer la photographie dans tous les domaines de la pensée culturelle [...] au ministère de la Culture, chaque direction a désormais une préoccupation et une action en la matière. ${ }^{52}$

The publically funded events of 1989 ranged from scholarly and more popular publication projects (the proceedings of a conference on Les Multiples inventions de la photographie at Cerisy and the world history of photography Histoire de voir by Frizot and Delpire),${ }^{53}$ to the

${ }^{51}$ Nori, La Photographie en France, p. 312.

52 Jack Lang, 'Conférence de presse sur la photographie', Interphotothèque. Actualités, 42 (1989), 14-16 (p. 14).

${ }^{53}$ See Gattinoni, La Photographie en France, pp. 38-9. 
creation of prizes and competitions, over sixty exhibitions all over the country, as well as educational initiatives. These latter were an extension of the already existing École nationale de la photographie in Arles (opened in 1982 and recognized as an École nationale supérieure in 2003) and the inauguration (in 1990) of a chair of photography history at the prestigious École du Louvre.

Since the 1980s, governmental initiatives concerning photography as spearheaded by the Ministry of Culture have been divided in four major categories. ${ }^{54}$ These are, firstly, the teaching of the history of photography in a wider educational context manifested not only in the aforementioned Écoles, but also in more targeted 'Ateliers de photographie' in lycées and collèges, or the integration of photography in university degrees, such as at Paris VII and AixMarseille I. Secondly, there have at least been attempts, not entirely successful, to institute legislation clarifying copyright laws, including a major amendment of the 1957 copyright law, which extended artistic copyright to photography. The third and final areas of involvement, the constitution and protection of the photographic patrimoine and the creation and dissemination of photographic work, are the most visible and dynamic ones. Whereas the activities of the Mission pour la photographie are the main vehicle for the coordination of the patrimoine, the CNP (and since 2004 the Jeu de Paume) is charged with delivering on political rhetoric with regards to major support for the creation and dissemination of photography. The latter goes beyond the traditional means of exhibitions and includes three further priorities: the development of more decentralized activities and institutions (of which the creation of branches of the Centre Pompidou in Metz, in 2010, and the Jeu de Paume in Tours, in the same year, are but some of the latest manifestations); a better coordinated

\footnotetext{
${ }^{54}$ The breakdown of activity described in this paragraph is taken from La Photographie. État et culture, pp. 54-97.
} 
editorial politics, which includes the administration of research funds; and activities that target the dissemination of France's photographic collections, heritage and events abroad.

However, in spite of this ambitious cultural politics with respect to photography, which may well be part of the oft-quoted 'exception française', ${ }^{55}$ overall the governmental initiatives under Mitterrand and his culture minister Lang were still rather reactive rather than proactive in comparison to the numerous private endeavours already underway in the 1970s, as has been discussed. It should also be noted that in terms of photographic theory, history and criticsm, by the early 1980s the medium was already a significant part of French intellectual discourse, not least through the highly influential theoretical works of Roland Barthes (La Chambre claire. Note sur la photographie, 1980); Philippe Dubois (L'Acte photographique, 1983); Jean-Marie Schaeffer (L’Image précaire. Du dispositif photographique, 1987); and the lesser-known Philosophie de la photographie by Henri Van Lier (1983). At the same time, a number of small publishing houses devoted reproducing photographic work emerged, ${ }^{56}$ and in terms of mass media, France's major daily newspapers Le Monde, Libération and Le Figaro started photography columns in their cultural sections. By way of conclusion, the complex and multifaceted landscape of photography in contemporary France has emerged out of a fruitful combination of individual enthusiasts as well as private enterprises, together with a slowly growing (if comparatively late) state commitment to photography arising in part as a reaction to new cultural activities and

\section{${ }^{55}$ See Poirrier, L'État et la culture, p. 9.}

${ }^{56}$ Nori's chronology provides a good overview of this perhaps under acknowledged field, $L a$ Photographie en France, pp. 295-305. As the founder of the gallery and publisher Contrejour in the 1970s, Nori is, of course, himself an important figure in this aspect of the history of photography in France. 
developments with regards to the medium in the country, and to photography's increasing institutionalisation as fine art outside of France. In contrast to the proactive foresight which underpinned the legal appropriation of the new invention of photography by the French government in 1839, in the late twentieth century, Mitterrand and his culture minister Lang reacted to new cultural and artistic practices surrounding photography on hindsight. Thus, while photography, in a twenty-first-century context, and in its now predominantly digital guise, is very clearly part of the officially recognized and supported French pantheon of the arts, and of culturally significant media more generally, as this brief overview has shown, this place has been hard won. In addition to the specifically French and cultural-political circumstances which have been traced, no doubt this is partly owing to the simultaneous, sometimes apparently contradictory or competing aspects of a fascinating medium with a bewildering variety of uses, functions and values. ${ }^{57}$

\footnotetext{
${ }^{57}$ I wish to thank Paul Smith for his perceptive comments and suggestions in relation to an earlier version of this article.
} 